\title{
Corporate Social Responsibility and Dividend Policy
}

\author{
Adrian (Wai Kong) Cheung \\ School of Economics and Finance, \\ Curtin University, Australia \\ adrian.cheung@curtin.edu.au \\ May $\mathrm{Hu}$ \\ Deakin Graduate School of Business, \\ Deakin University, Australia \\ may.hu@deakin.edu.au \\ Jörg Schwiebert \\ Institute of Economics, \\ Leuphana University Lüneburg, Germany \\ schwiebert@leuphana.de
}

\section{ABSTRACT}

This paper outlines and tests two corporate social responsibility (CSR) views of dividends.

The first view argues that firms are likely to pay fewer dividends because CSR activities lower the cost of equity, encouraging firms to invest or hoard cash rather than to pay dividends. The second view suggests that CSR activities are positive NPV projects that increases earnings and hence dividend payouts. The first (second) view predicts that firms with a stronger involvement in CSR activities should be associated with a lower (higher) dividend payouts. The finding supports the second view and is robust.

Keywords: Corporate social responsibility; Dividends;

JEL Classification Codes: G35, G30, G32 


\section{Corporate Social Responsibility and Dividend Policy}

\section{ABSTRACT}

This paper outlines and tests two corporate social responsibility (CSR) views of dividends. The first view argues that firms are likely to pay fewer dividends because CSR activities lower the cost of equity, encouraging firms to invest or hoard cash rather than to pay dividends. The second view suggests that CSR activities are positive NPV projects that increases earnings and hence dividend payouts. The first (second) view predicts that firms with a stronger involvement in CSR activities should be associated with a lower (higher) dividend payouts. The finding supports the second view and is robust. 


\section{Introduction}

The relationship between corporate social responsibility $(\mathrm{CSR})^{1}$ and finance has received much attention from academics, the media and the business community for many years. Much of the attention is centered on the relationship between CSR and corporate financial performance in general. Interestingly, there are mixed and often conflicting results in early studies (see the surveys by Orlitzky, Schmidt, and Rynes, 2003; Margolis, Elfenbein, and Walsh, 2009), while recent studies tend to confirm a positive link between CSR and corporate financial performance (see Wang, Dou and Jie, 2015). This lack of consistent results has prompted researchers to tackle the issue from a different perspective. In particular, finance scholars have started to explore the link between CSR and specific aspects of finance because CSR may not necessarily affect specific aspects of financial performance in the same way, resulting in different scenarios where overall corporate financial performance, as a net indicator of these effects, can be positively, negatively or not related to $\mathrm{CSR}^{2}$

There are two main approaches of relating CSR to specific aspects of finance in the literature. The first approach argues that CSR affects market valuations (Gregory, Whittaker, and Yan, 2011; Manescu, 2011) through channels such as future income/profitability, risk and expected return. By examining specific channel(s), one may understand how CSR enhances or worsens different aspects of corporate financial performance. This approach implicitly

\footnotetext{
${ }^{1}$ CSR goes by many names and has several variants. We refer generally to CSR as the inclusion of environmental, social and governance concerns in corporate decision-making. This approach is also consistent with the Environmental, Social and Corporate Governance (ESG) framework of CSR on which our data on CSR are based.

${ }^{2}$ Recently, there has been renewed interest in the literature focusing on specific dimensions of CSR (e.g., environmental, social or governance) and their separate relationships with corporate financial performance. This approach is sometimes called strategic CSR (see Baron, 2001; Porter and Kramer, 2006).
} 
assumes that capital market valuation is correct. To avoid this controversial assumption, the second approach aims to examine the possible link(s) between CSR and key finance decisions, such as investment (Manescu and Starica, 2007), capital structure (Pijourlet, 2014), mergers and acquisitions (Deng, Kang, and Low, 2013) and corporate cash holdings (Arouri and Pijourlet, 2015; Cheung, 2016). This approach typically extracts information about key financial decisions from financial statements. However, very little work has been done on dividend policy; Rakotomavo (2012) is the only paper that touches on this issue. It examines a specific issue on the relationship between investment in CSR and expected dividend and finds that CSR investments do not take away from expected dividends. ${ }^{3}$

Following the second approach, the objective of this paper is to examine the relationship between CSR and dividend policy. To this end, we develop and empirically test two CSR views of dividends. The first view, called "the equity cost of the capital channel", posits that CSR-related activities lower the cost of equity through its risk premium (Ghoul, Guedhami, Kwok, and Mishra, 2011), which would encourage firms to hold cash or invest instead of paying out cash dividends. According to Kim, Mauer, and Sherman (1998), the incentive for firms to hold cash is higher (lower) when the cost of capital is lower (higher) because the opportunity cost of hoarding cash is lower (higher). Firms' incentive to invest can be higher (lower) too, since the external financial constraint is less (more) binding on firms when the cost of capital is low (higher). Therefore, firms may invest more and leave less room for paying dividends. This implies that CSR is negatively related to dividend payout. The second view, called "the earnings channel", argues that CSR-related activities can enhance earnings for various reasons such as better relationships with stakeholders, efficient management

\footnotetext{
${ }^{3}$ This paper is different from Rakotomavo (2012) in a number of ways. See the "Literature review and hypotheses development" section for details.
} 
and so on (Heal, 2005). Good relationships with stakeholders can reduce transaction costs (Jones, 1995), enhance competitive advantage (Hillman and Keim, 2001; Choi and Wang, 2009) and reduce the cash flow shock when a negative event occurs (Godfrey, Merrill, and Hansen, 2009). Therefore, firms with strong presence in CSR-related activities are expected to have higher output or income with a lower level of risk. The stronger earnings ability can result firms to be in a better position to pay and/or to pay more in dividends. The main results of this paper support the second view. We find evidence that firms with higher CSR scores tend to have a higher dividend payout ratio; however, we cannot find evidence that the decision to pay or not to pay dividends is determined by CSR scores.

This paper contributes to the literature in at least three ways. First, it fills an important gap in the literature on CSR and finance as little work has been done on the relationship between CSR and dividend policy. ${ }^{4}$ Second, it examines the relationship between CSR and dividend policy in a comprehensive manner. In particular, we examine not only the dividend payout ratio (i.e., what dividends are paid?) but also the propensity to pay dividends (i.e., how likely is a firm to pay dividends?). The literature on dividend policy typically deals with the propensity to pay dividends and the dividend payout ratio separately. However, it is important to recognize that non-dividend paying firms choose to pay no dividends. As Heckman (1979) points out, as long as this decision is non-random, any analyses based on dividend-paying firms only may suffer from self-selection problem. The failure to account for the correlation between these two decisions is susceptible to inconsistent estimation. In fact, our evidence suggests that the propensity to pay dividends and the dividend payout ratio are, at least in our sample, not independent of each other. Third, we report empirical

\footnotetext{
${ }^{4}$ See the "Literature review and hypotheses development" section for details.
} 
evidence that clearly clarifies the role of CSR in dividend policy. It is a driver of the dividend payout ratio but not a driver of the propensity to pay dividends.

\section{Theoretical background and hypothesis}

It is well documented that the market valuation effects of social norms are significant (Hong and Kacperczyk, 2009). The market valuation approach suggests that two forces are at work. First, firms with better CSR are expected to improve their future cash flows (or profitability) (Manescu and Starica, 2007), which can be distributed to shareholders. For example, firms may benefit by positioning themselves to take advantage of CSR-driven market opportunities (Porter and Kramer, 2006; Siegel and Vitaliano, 2007) and/or by incorporating all social costs or externalities and pricing goods and services accordingly (Heal, 2005; Johnston, 2010). The second channel works through a reduction in the cost of capital, which is used to discount expected cash flows. For example, firms with better CSR are associated with lower (systematic) risk (Albuquerque, Durnev, and Koskinen, 2014), the cost of debt/bank loans (Goss and Roberts, 2011; Menz, 2010), the cost of equity (Ghoul, et al., 2011; Dhaliwal, Li, Tsang, and Yang, 2011) or the cost of capital (Hart and Ahuja, 1996; Sharfman and Fernando, 2008). Apart from the issue that capital market data are noisy, a potential drawback of this approach is that future profitability, risk and the cost of capital cannot be examined in isolation because they are likely to be determined simultaneously.

Studies of the relationship between dividend policy decisions and CSR are scant. To our knowledge, Rakotomavo (2012) is the only paper in the literature. However, it examines a specific issue on the relationship between investment in CSR and unexpected dividends and 
finds that CSR investments do not take away from expected dividends. This paper differs from Rakotomavo (2012) in the following ways. First, the measure of CSR that his paper uses is restrictive because it considers CSR strengths only and ignores another important dimension of CSR (i.e., weaknesses) that may also determine dividend policy in an important way. We use a measure of CSR that makes use of information on both strengths and weaknesses. Second, his measure of unexpected dividends is a model-specific measure that may be sensitive to how the model for expectation is specified and estimated. ${ }^{5}$ Following DeAngelo, DeAngelo and Skinner (2004) and Chay and Suh (2009), we use the actual dividend payout ratio as a measure of dividend policy because it is a model-free measure and suffers no estimation problems. Third, his paper does not examine the issue of the propensity to pay dividends. It is our view that this issue is very important because more than half of CSR firms in our sample do not pay any dividends over time and they tend to pay no dividends persistently, resulting in the zero-inflation problem (i.e., a statistical problem associated with excess zero observations). ${ }^{6}$ It is not clear whether this zeroinflation problem affects his findings. ${ }^{7}$ In addition, it is noteworthy that non-dividend-paying firms choose to pay no dividends. If this decision is non-random (i.e., based on systematic factors), then analyses based only on dividend-paying firms may suffer from self-selection bias. It is therefore important to account for the relationship that may exist between the propensity to pay dividends and the dividend payment decision. The failure to control for this relationship results in a biased estimation because of the sample selection problem

\footnotetext{
${ }^{5}$ More specifically, his expectation model is just an OLS regression of current dividends against current earnings and lagged dividends; this model is known to suffer from biased or inconsistent estimation in the presence of unobserved heterogeneity and cross-sectional dependence (Phillips and Sul, 2007).

${ }^{6}$ See the "Methodology" section for further information on this issue.

${ }^{7}$ If all data are used, then these data will suffer from the over-dispersion problem because of excessive zeros. If only the data greater than zero are used in the analysis, important information about firms with zero dividends is lost, and estimates of the totals will not include zero values. When one is relying on estimates from such analyses to make dividend policy decisions, inaccurate conclusions may be made, which could lead to policies that are inadequate or inappropriate for the population of interest.
} 
(Heckman, 1979). Fourth, after controlling for the zero-inflation problem and self-selection problem, we find that the CSR score does not affect the propensity to pay dividends but does influence the dividend payout ratio. Consistent with the finding of Rakotomavo (2012) that firms with higher CSR scores do not reduce any dividends, we find that firms with higher CSR scores tend to have a higher payout ratio.

In theory, CSR can affect dividend policy through two major channels. One is the earnings channel and the other one is the cost of equity capital channel. ${ }^{8}$ The earnings channel depicts that CSR may affect earnings, which in turn affects dividend policy. It has been well documented in the literature that earnings are a key determinant of dividend policy (see, for example, Gul, 1999; Michaely and Roberts, 2012). Firms with higher earnings ability are more likely to pay dividends, and if they do, they will pay more in dividends. Heal (2005) argues that CSR can enhance earnings through better relationships with stakeholders, more efficient management, better asset allocation, better labor policies and other efficiency improvements. Such benefits are expected to flow through to investors in the form of increased earnings and strong dividend policies, resulting in a win/win scenario for firms, investors and stakeholders (Statman, 2000). Empirical studies seem to support this view. For example, good relationships with stakeholders can reduce transaction costs (Jones, 1995), enhance competitive advantage (Hillman and Keim, 2001; Choi and Wang, 2009) and reduce the cash flow shock when a negative event occurs (Godfrey, Merrill, and Hansen, 2009). Vitaliano (2010) reports evidence that firms that adopt CSR-consistent business policies

\footnotetext{
${ }^{8}$ One may argue that there is another channel called the risk (or risk premium) channel. In our view, the risk channel can be embedded into the cost of capital channel. The concept of the cost of capital can be decomposed into two components. One is the risk-free rate and the other is the risk premium. Any change in risk is presumably captured by the corresponding change in the risk premium, which in turn affects the cost of capital.
} 
reduce the annual labor turnover rate by $3-3.5 \%$, which amounts to a $25-30 \%$ reduction compared with other firms that do not adopt such policies. The positive link between CSR and earnings is also confirmed in recent meta analytic studies such as Wang, Dou and Jie (2015). ${ }^{9}$

The cost of equity capital channel argues that CSR may lower the cost of capital, which in turn encourages firms to hold cash or invest instead of paying out cash dividends. The underlying economic principle is simple and well-documented in the literature (see, for example, Kim, Mauer, and Sherman (1998)): whenever the cost of capital is lower (higher), a firm's incentive to hold cash is expected to be higher (lower) because the opportunity cost of hoarding cash is also lower (higher). A firm's incentive to invest is expected to be higher (lower) too because whenever the cost of capital is low (high), the external financial constraint is less (more) binding on firms. Thus, firms without a binding financial constraint can now accept projects that were otherwise not feasible (due to the limited supply of external finance) and/or not profitable (due to the higher cost of capital), leaving less room for paying dividends, while firms with such a constraint cannot. These two incentives could generate a crowding-out (crowding-in) effect on dividends whenever the cost of capital is low (high). ${ }^{10}$

CSR lowers the cost of capital because it can reduce the risk premium associated with the cost of capital. The risk premium is perceived to be smaller because firms with higher CSR

\footnotetext{
${ }^{9}$ The early meta analytic evidence (i.e., up to 2002) on the link between CSR and earnings is mixed. See Orlitzky, Schmidt, Rynes (2003).

${ }^{10}$ For a technical discussion of the same issue in a dynamic setting, see Akyildirim, Guney, Rochet and Soner (2014).
} 
scores tend to be less risky and associated with better corporate governance (Harjoto and Jo, 2011), stronger loyalty from investor or customer (Luo and Bhattacharya, 2009; Albuquerque et al., 2014; Jo and Na, 2012), good reputation or social capital (Luo and Bhattacharya, 2009), and/or larger investor bases with less information asymmetry problems (Ghoul et al., 2011).

It is noteworthy that the impact of CSR on dividend policy is positive in the first channel, while it is negative in the second channel. As these two channels may coexist, the overall impact of CSR on dividend policy depends on which channel dominates. In view of this, we formulate several hypotheses for the two channels:

The earnings channel predicts the following:

H1: Among those firms that pay dividends, firms with higher CSR scores tend to pay more.

The predictions of the cost of equity capital channel are:

H2: Among those firms that pay dividends, firms with higher CSR scores tend to pay less.

Note that the literature currently does not offer if, and why, CSR may be a determinant of propensity to pay dividends. As a result, we set the following hypothesis:

H3: Other things being equal, CSR scores are not associated with propensity to pay dividends.

\section{Empirical tests}

\subsection{Measurement of key variables}

We use CSR measures from Kinder, Lydenberg and Domini (KLD) of 1,965 firms from 1991 to 2010. These KLD measure scores are derived from the Environmental, Social and Corporate 
Governance (ESG) framework of corporate social responsibility. Broadly speaking, the "E" dimension is the environment, the " $S$ " dimension consists of three sub-dimensions (namely, community relations, human rights and product safety) while the " $G$ " dimension covers another three sub-dimensions (corporate governance, diversity \& employee relations).

Each of these seven sub-dimensions is rated yearly based on a number of positive (strength) and negative (weakness) indicators. These indicators are dummy variables that are given a score of 1 if a particular strength (or weakness) is present and otherwise 0 . The total number of indicators has varied from 54 in 1991 to 74 in 2007. The strengths and weaknesses of each dimension are then aggregated to give an overall score for that dimension. Several popular aggregate methods have been used in previous studies based on KLD data (e.g., Derwall and Verwijmeren, 2007; Kempf and Osthoff, 2007; Chatterji, Levine, and Toffel, 2009). However, Manescu (2011) points out some potential limitations of these aggregation methods, including the lack of comparability across years and across dimensions due to the varying number of indicators over time and inflated KLD scores for industries that are not sensitive to certain ESG dimensions (such as the environment, community relations, human rights and employee relations).

Following Deng et al. (2013), we use the relative aggregation method, which is designed to minimize the potential drawbacks of the KLD data. The formula of the relative aggregation method is shown below:

$$
\operatorname{CSR}_{t}^{i}=\frac{\sum_{p=1}^{n_{t}^{i}} \text { Strength }_{p}^{i}}{n_{t}^{i}}-\frac{\sum_{q=1}^{m_{t}^{i}} \text { Weakness }_{q}^{i}}{m_{t}^{i}}
$$


where $C S R_{t}^{i}$ is the CSR score for dimension i at time $\mathrm{t}$; $\operatorname{Strength}_{p}^{i}$ is the $\mathrm{p}^{\text {th }}$ strength indicator for dimension $\mathrm{i}$ at time $\mathrm{t}$; Weakness ${ }_{q}^{i}$ is the $\mathrm{q}^{\text {th }}$ strength indicator for dimension $\mathrm{i}$ at time $t$ (both indicators are dummy variables that equal 1 if the firm meets strength $p$ or weakness $q$, otherwise 0 ); and $n_{t}^{i}$ and $m_{t}^{i}$ are the total number of strength and weakness indicators, respectively, at time t. As both strength and weakness indicators are first summed and then averaged each year before the CSR score is computed, this procedure ensures that year-to-year comparison can be done meaningfully. Note that the CSR score so computed is easy to interpret, as by construction it lies between -1 and +1 . The aggregate CSR score is just a simple average of the CSR scores of the seven dimensions.

To examine the impact of CSR on dividend policy, we look at two dimensions: the propensity to pay dividends (i.e., how likely is a firm to pay dividends?) and the dividend payout ratio (i.e., what dividends are paid?). Following DeAngelo et al. (2004) and Chay and Suh (2009), we compute the dividend payout ratio (payout) as follows:

payout $=$ dividends per share $($ DVPSX_F $) /$ diluted earnings per share $(E P S F X)$.

we use a set of control variables to capture firm characteristics that may affect dividend policy (Gul, 1999; Fama and French, 2001; Hoberg and Prabhala, 2008; Michaely and Roberts, 2012). The details of these variables are illustrated in Appendix A.

We control for earnings for two reasons. First, firms with high profitability are more likely to pay dividends and if they do, pay more dividends (Fama and French, 2001, 2002). Thus, earnings to total assets (eta), as a proxy for earnings, is expected to be positively related to the propensity to pay dividends and the dividend payout decision. Second, recall that one of 
the channels through which CSR may affect dividend policy is the earnings channel. It is important to control for earnings because some known and unknown factors other than CSR could also affect dividend policy via earnings.

Retained earnings as a proportion of total assets (reta), as a proxy for the firm life cycle, is expected to be positively related to the propensity to pay, as DeAngelo et al. (2006) and Banyi and Kahle (2014) show that firms with lower reta are less likely to pay dividends, while firms with higher reta are more mature and thus more likely to pay.

Agency theory argues that dividends can provide a disciplinary mechanism to reduce and limit managerial power because it can decrease the amount of free cash flow (agency problem) and increase the incentive for managers to put funds into profitable investments (Jensen, 1986). However, other mechanisms are available to serve a similar purpose and they include investment opportunities (measured by the market-to-book ratio) and debt (measured by leverage). Whether these mechanisms are complementary or substitutes depends on the relative costs of these mechanisms. For example, if interest rates are low (high), firms find many investment opportunities profitable (not profitable) and firms with more (less) investment opportunities tend to retain more (less) of their earnings to finance new investments (Myers, 1984). This line of reasoning suggests that the relationship between dividends and investment opportunities can be positive or negative. Similarly, firms also find it relatively easy (difficult) to raise more money in the form of debt financing and pay more dividends in a low (high) interest rate environment. It is not unreasonable to see that leverage and dividend payouts are both positively (negatively) correlated in such a low (high) interest rate environment. However, for those high-leverage firms, their financial 
risk is expected to be higher and so is their interest burden, suggesting that these firms find it luxurious to pay dividends. Thus, leverage is expected to be negatively related to the propensity to pay.

The cost of equity capital ( $r_{-}$com) is used as a control variable because it is a channel through which CSR may affect dividend policy. As discussed in the "Hypothesis development" section, a lower cost of capital can encourage firms to hold cash or invest instead of paying out cash dividends. Therefore, the cost of capital is expected to be positively related to the dividend payout decision. We employ a recently developed method proposed by Hou, Van Dijk and Zhang (2012) to compute the cost of equity capital.

\subsection{Data and Sample Selection}

We obtain the data required for this study from Compustat and match it with the KLD data. The initial sample consists of all firm-year observations spanning the period 1991-2010. After excluding financial firms (SIC codes 6000-6999) and utilities (SIC codes 4400-4999), the sample is further filtered with the requirements that all firms to be included must have no negative or zero book assets, and no missing values for the key variables. ${ }^{11}$ To reduce the influence of outliers, we winsorize $1 \%$ of the sample on both sides. The final sample is an unbalanced panel data that consists of 15,561 firm-year observations. There are 1,965 firms in the sample with an average number of years being approximately six.

\footnotetext{
${ }^{11}$ Note that construction of the cost of equity capital variable requires analysts' earnings forecasts from IBES. But IBES database does not cover all of the sample firms. Thus, the construction of this variable results in a substantial reduction of valid observations from 20,614 firm-year observations to 15,561 firm-year observations. For details, see Table 1.
} 
Table 1 shows the (effective) number of firms across the years in the sample. The sample starts with 269 firms in 1991, increases steadily over time to 600 firms in 2002 and then jumps up to around 1,200 firms in 2003. In 2010, there are 1440 firms in the sample. ${ }^{12}$ The significant increase in the number of firms in 2003 is because KLD expanded the universe of sample firms to include an additional 1,000 firms from the Russell 2000 index in that year.

\subsection{Methodology}

Figure 1 shows that the data for the dividend payout ratio are right-skewed, involving a substantial proportion of zero values because many firms do not pay dividends. This gives rise to a statistical or econometric problem called the zero-inflation problem. Analyzing zero-inflated data as though they were normal may lead to biased or inconsistent estimates, inflated standard errors and inappropriate inference because the data are often skewed, heteroskedastic and over-dispersed (see Min and Agresti, 2002 for a survey). In addition, non-dividend-paying firms are quite persistent over time. Once they do not pay dividends, the chance of these firms continuing not to pay dividends is very high, as shown by Table 2 where the transition probability of dividend-paying firms (i.e., payer) and non-dividendpaying firms (i.e., nonpayer) are shown. The transition probability of the status quo of nondividend-paying firms is $91.83 \%$, while that of dividend-paying firms is $92.61 \%$, confirming that they are quite distinct groups of firms. This begs the question of whether the decision to pay or not to pay dividends (i.e., the propensity to pay dividends) should be modeled separately from the decision of what dividends to pay (i.e., the dividend payout decision). If

\footnotetext{
${ }^{12}$ Note that Hou et al.'s (2012) method of computing the cost of equity capital is constrained by the data availability of analysts' forecast on earnings per share in IBES. As not all sample firms have valid observations on analysts' forecasts on earnings per share in IBES, the construction of this variable results in a substantial loss of observations in the sample. In particular, more than 500 firms are lost with this filtering requirement. This loss is, relatively speaking, not as severe as in the case of another method proposed by Hou et al. (2012) based on the cross-sectional earnings regression model.
} 
the former decision is not random and affects the latter decision, then to estimate the latter decision based on those firms that pay dividends may suffer from the sample selection problem or self-selection problem (Heckman, 1979). ${ }^{13}$

To deal with both the zero-inflation problem and the sample selection problem, we use a standard Heckman sample selection model ${ }^{14}$ that breaks down the dividend policy into two sub-decisions and models them separately. The first one is the decision to pay or not to pay dividends (i.e., the propensity to pay decision) and the second one is the decision to determine the amount of dividends (i.e., the dividend payment decision). Specifically, the model handles zeros and positive values separately through two equations: the selection equation for the probability of paying dividends (i.e., $Y>0$ ) and the main equation for the strictly positive value of the dividend payment conditional on its payment (i.e., $Y \mid Y>0$ ). We also allow for the possibility that these two decisions are related to each other; they are then linked together by imposing a correlation structure on the error terms that appear in the two equations. Heckman (1979) points out that the failure to account for the correlation between these two equations is susceptible to inconsistent estimation due to the sample selection problem. Please see the detail in Appendix B.

\section{Empirical results}

\footnotetext{
${ }^{13}$ The sample selection problem occurs when the outcome of interest is only observed for a non-randomly selected sub-population. In our context, the outcome of interest is dividend payout, which is only observed among those firms that pay dividends. To the extent that dividend-paying firms are not the same as nondividend-paying firms, a simple OLS regression based on dividend-paying firms is inconsistent.

${ }^{14}$ According to the econometric literature, one might consider censored regression models in this panel data setting. However, because the decision not to pay dividends is a choice of the firm, meaning that zeros in the dividend payout ratio are observed true values rather than censored values, censored regression models such as Tobit models are not considered in this paper.
} 
Figure 2 plots the evolution of the annual average of the dividend payout ratio and the CSR score over time. As Fama and French $(2001,2002)$ point out, the annual average of the dividend payout ratio (represented by the upper line) is on a downward trend during the period 1990 to 2003 . Then, it flattens out somewhat in 2004 to 2006 before it takes off from 2006. The annual average of the CSR score is mostly positive during the period 1991 to 1997. After that, it remains in negative territory until 2010. It is not difficult to see that the annual averages of these two variables generally move in line with each other, suggesting that they are correlated.

Table 3 shows the summary statistics of the key variables. Owing to the zero-inflation problem, the dividend payout ratio (payout) suffers from over-dispersion, meaning that its sample variance $(25.4 \%)$ is much larger than its sample mean (15.2\%). Over-dispersion implies that the empirical density is skewed with most of the probability for low values of the variable being larger than that for high values. The average sample firm is characterized as a firm of medium size (nysep $\approx 49.1 \%$ ), with some growth opportunities ( $m t b>2$ ) and earnings power (eta $\approx 6 \%$ ) but with a reasonable amount of retained earnings (reta $=12 \%$ ) and large cash holdings (cash $\approx 15.8 \%$ ), low leverage (lev $<22 \%$ ), average systematic risk $($ beta $\approx 1)$ and high idiosyncratic risk (idio $=2.353)$. The CSR score of the average sample firm is a little bit below zero (i.e., -0.013 ).

Columns (1) and (2) of Table 4 show the parameter estimates of the standard two-step estimation method for the Heckman sample selection model where the dependent variable is (the log of) dividends payouts. The coefficient of the inverse Mills ratio is 0.740 and 
statistically significant at conventional levels. This finding suggests the presence of sample selection bias.

It is noteworthy that CSR does not affect the propensity to pay dividends but does influence the dividend payout ratio because the coefficient of CSR is 0.194 and not statistically significant in the selection (the propensity to pay) equation, while it is 0.237 and statistically significant at conventional levels in the main (dividend payout) equation. In other words, CSR is a driver of the dividend payout ratio but not of the propensity to pay because firms with high CSR scores are as likely to pay dividends as those with low CSR scores. Among those firms that pay dividends, firms with high CSR scores tend to pay more dividends out of their earnings. In particular, a 0.1 unit increase in the CSR score will give rise to a $2.37 \%$ increase in the log of the dividend payout ratio. This is equivalent to a $2.398 \%$ $(=(\exp (0.237) * 0.1-1) * 100 \%)$ increase in the dividend payout ratio, suggesting that the corresponding change is highly economically significant. ${ }^{15}$

Consistent with the findings of Gul (1999), DeAngelo et al. (2006) and Hoberg and Prabhala (2008), the selection equation results indicate that the propensity to pay is positively related to earnings (eta), firm life cycle (reta), firm size (nysep) and whether the firm was a dividend-payer in the previous year (payer), but negatively related to the leverage ratio (lev), cash holdings (cash), risks (beta and idio) and the cost of capital ( $r_{-}$com). In other words, mature firms with good earnings power, large market capitalization and a track record of paying dividends are more likely to pay dividends, while firms with a high level of cash

\footnotetext{
${ }^{15}$ Instead of using a standard analysis with a unit change in the variable, we use a 0.1 unit change because our CSR measure, by construction, must lie between +5 and -5 . This implies that a unit change in CSR is equivalent to a $10 \%$ change in CSR and admittedly too large.
} 
balances, debt, risks and financing cost are more likely not to pay. We use as an exclusion restriction three variables recently proposed by Banyi and Kahle (2014) as new determinants of the propensity to pay. They are the decade in which a firm goes IPO (ipo90), its interaction with firm life cycle (reta*ipo90) and tax regime during which there is a dividend tax cut (taxregime); they are all statistically significant at conventional levels.

Among those firms that pay dividends, the main equation results show that firms that tend to have a low dividend payout ratio are mature and large firms with little earnings and cash, but with a high level of risks and stock buyback activities. Interestingly, dividend-paying firms with a high level of debt and cost of capital also tend to pay more dividends out of their earnings probably because of the low interest rate environment prevailing in the sample period.

It is interesting to note that most of all control variables are statistically significant and some of their coefficients are of different signs in the two equations of the model. This finding suggests that these control variables play different roles in determining the propensity to pay dividends and the dividend payout ratio, respectively. These variables include firm size, leverage, the cost of capital, cash and retained earnings.

\section{Robustness Checks}

\subsection{FIML estimates of the Heckman sample selection model}

The two-step estimator is consistent but not asymptotically efficient. The FIML estimation can provide efficient estimates. In view of this, we report the FIML estimates in Columns (3) and (4) of Table 4. The FIML results are very similar to the two-step results. All of the 
variables keep their signs and statistical significance as in the two-step results shown in Columns (1) and (2). In addition, most of the regression coefficients are similar in magnitude to that of the two-step results. The only difference is that the (robust) standard errors are, as expected, generally smaller with the FIML estimates. The evidence that the correlation (rho) is positive and statistically significant supports the view that the error terms of the main equation and the selection equation are positively correlated. Consistent with this evidence, the Wald test statistic rejects the null hypothesis that the two equations are independent of each other because the statistic is 20.87 and statistically significant. This finding is important in the sense that any conclusions based on previous studies that examine the dividend payout decision or the propensity to pay separately need to be reexamined.

The FIML results also show that csr does not affect the selection (the propensity to pay) equation but does influence the main (dividend payout) equation. A 0.1 unit increase in csr is associated with a $13.08 \%$ increase in the dividend payout ratio.

\subsection{Joint Normality of the Error Terms}

Zuehlke and Zeman (1991) report Monte Carlo simulation evidence that the violation of the joint normality assumption underlying the error terms of the Heckman sample selection model results in biased and imprecise estimates. Following Smith (2003), we use the copula approach to re-estimate the same model, allowing for different assumptions on the joint distribution of the error terms in the main and selection equations. The main idea of the copula approach is based on a mathematical theorem called Sklar's theorem, which shows that there exists a copula function that can represent the joint distribution of random 
variables in terms of its underlying one-dimensional marginal distributions. It implies that regression with this copula function can capture the dependence characteristics between the error terms in a flexible way. Many copula functions (Product, Gaussian, Clayton, Frank, Gumbel and Joe copulas) and commonly used marginal distributions (normal distribution, logistic distribution and t distribution) have been proposed in the literature because of their ability to characterize different types of dependence structures. (see, for example, Smith, 2003 or Nelsen, 2006 for further discussions). We first estimate the Heckman sample selection model with all the possible combinations of the above different assumptions on the marginal distributions and the copula function, and then we use the Akaike Information Criterion (AIC) to select the combination of the assumptions that provides the best fit of the model to the sample data. This process ends up with the one with the logit-logistic marginal distributions and Joe copula. This model has the lowest AIC (i.e., 24,118.403) of all specifications. The Joe copula is particularly good at detecting asymmetric tail dependence because it can exhibit strong dependence in the upper tail but weak dependence in the lower tail. The estimation results are reported in Table 5.

Consistent with Table 3, where the coefficient of the inverse Mills ratio is statistically significant, Table 5 shows that the error terms of the main equation and the selection equation are not independent, as the Wald test statistic (47.553 and statistically significant) rejects the null hypothesis that they are independent of each other. The coefficient of the inverse Mills ratio is 1.339 and statistically significant, confirming the presence of the sample selection problem. As in Table 3, the coefficient of csr is positive in both the main equation and the selection equation but it is only statistically significant in the former. This evidence is important in the following sense. First, it suggests that our main findings still 
hold even though the joint normality assumption is relaxed. Second, the dependence structure of the error terms seems to be an asymmetric one because dependence is stronger in the upper tail but not in the lower tail; any positive shock in the selection equation can give rise to a similar shock in the main equation but a negative shock does not have a similar effect.

\subsection{Endogenous CSR and alternative explanation}

We also explore the robustness of our findings by examining some endogeneity issues with the Heckman sample selection model. This model employs a restrictive assumption that the explanatory variables are exogenous in the sense that they are independent of the error terms, ruling out any endogeneity problems that may exist in the model. In other words, some unobserved variables are omitted from the model but they drive the explanatory variables to be correlated with the error terms in the model. For example, agency problems, which are not directly observable, may drive both csr and dividend policy move together. The agency view of CSR predicts that CSR activities can be used by executives to extract their private benefits and/or to pursue their own interests (Surroca and Tribo, 2008; Jiraporn and Chintrakarn, 2013; Fabrizi, Mallin, and Michelon, 2014), while the agency view

of dividend policy suggests that dividend policy can address agency problems between managers and shareholders (La Porta, Lopez-de-Silanes, Shleifer and Vishny, 2000). In view of this, we first incorporate 48 Fama-French industry dummies and year dummies into our empirical model to capture other firm characteristics that are unobservable and/or 
unknown to us but may explain the main and selection equations. ${ }^{16}$ Second, we use the instrumental variable estimation method to deal with the possibility that csr is likely to be endogenous (see, for example, Garcia-Castro, Ariño, and Canela, 2010; Deng et al., 2013).

It is noteworthy that our setting is not a standard one in the sense that csr appears in both the selection equation and the main equation. This also means that both the equations are likely to suffer from the endogeneity problem. Standard econometric techniques for the Heckman selection model with endogenous variables (such as Wooldridge, 1995 and Semykina and Wooldridge, 2010) are available but they typically deal with the endogeneity problems in either the selection equation or the main equation but not both. ${ }^{17}$ To deal with the endogeneity issue in this special setting, we use a new procedure recently developed by Schwiebert (2015). In particular, we apply the FIML estimation approach, which simultaneously estimates the parameters of the selection equation, the main equation and an additional equation called the first-stage regression, where the regression of csr on all exogenous variables is estimated. ${ }^{18}$ The advantage of this procedure is that it can deal with the sample selection problem and the endogeneity problem in both the equations together.

Following Deng et al. (2013) and Di Giuli and Kostovetsky (2014), we use an instrument called red state (redstate) to proxy for csr in the first-stage regression. We use Deng et al.

\footnotetext{
${ }^{16}$ We do not consider sample selection models with firm fixed effects for two reasons. First, Dustmann and Rochina-Barrachina (2007) show that popular panel data fixed effects estimators for sample selection models such as Wooldridge's (1995) estimator, Kyriazidou's (1997) estimator and Rochina-Barrachina's (1999) estimator are considerably sensitive to the hidden (and untested) parametric assumptions they employ and can lead to conflicting results. Second, the FIML method with fixed effects at the firm level may suffer from the incidental parameter problem.

${ }^{17}$ In addition, Semykina and Wooldridge's (2010) technique also imposes a restriction that the dataset must be balanced.

${ }^{18}$ This equation is called the first-stage regression because it resembles the first-stage regression in the instrumental variable estimation method.
} 
(2013) approach to construct the dummy variable redstate, which equals 1 if a firm's headquarters is located in a red (Republican) state and 0 otherwise. The information about whether a state is a red (Republican) or blue (Democratic) state is available at the US Electoral College (http://www.archives.gov/federal-register/electoralcollege/historical.html). We use this instrument because it has been found to be correlated with csr (Deng et al., 2013; Di Giuli and Kostovetsky, 2014) and it is unlikely to have a significant effect on the firm's dividend policy. Di Giuli and Kostovetsky (2014) argue that "political affiliation is a natural measure of preferences for social responsibility. The Democratic Party platform places more emphasis on CSR-related issues such as environmental protection, anti-discrimination laws and affirmative action, employee protection, and helping the poor and disadvantaged" (p.159) and report evidence that csr scores are associated with the political affiliation of external stakeholders of firms (measured by voting patterns in the state where the firm is headquartered). In particular, Democratic-leaning firms are more socially responsible than Republican-leaning firms in the sense that they spend more on CSR.

To construct the instrument, we first extract data on a firm's headquarters address from its annual reports (i.e., 10-K and related reports) on SEC's Edgar website and find out the state in which the firm's headquarters is/was located. We then match the state with the list of blue or red states developed from the electoral results available at the US Electoral College's website and identify whether that state is a blue or red state in a particular year.

The estimation results are reported in Table 6. After controlling for endogeneity, Table 6 shows a similar result to Table 4. Column (3) of Table 6 indicates that redstate is a good 
instrument that does not suffer from any weak instrument problem because the F-statistic from the first-stage regression is 23.136 (i.e., far greater than 10). ${ }^{19}$ Note that both the main equation and the selection equation include an additional variable called eps, which is the error term from the first-stage regression. Its appearance in these two equations is needed to control for the potential endogeneity of csr; for details, we refer to the Schwiebert (2015) paper. Since eps is significant in both equations, this indicates that the endogeneity of csr is indeed present.

Consistent with our main findings, Column (2) shows that csr cannot explain the propensity to pay in the selection equation because its coefficient is -5.952 and statistically insignificant. Column (1) shows that the coefficient of $\operatorname{csr}$ (i.e., 8.887) in the main equation (i.e., the dividend payout decision) is positive and also statistically significant, meaning that firms with higher CSR scores tend to have a higher dividend payout ratio. In particular, if csr is increased by 0.01 units, the dividend payout ratio increases by $9.294 \%$ (=exp $\left(8.887^{*} 0.01\right)$ 1)*100\%).

\subsection{Reverse causality}

Reverse causality is a potential source of endogeneity. One may argue that it is dividend policy which affects csr because csr, especially when viewed as a kind of investment, is constrained by the amount of cash available for investment purpose. Given the fact that dividend policy is sticky, the amount of dividends payable may restrict the amount of money

\footnotetext{
${ }^{19}$ Staiger and Stock (1997) and Stock and Yogo (2005) develop a test commonly called the $1^{\text {st }}$ stage $\mathrm{F}$ test as pre-test for weak instruments. This test rejects the null hypothesis of weak instruments if the 1st-stage $F$ statistic is bigger than 10 .
} 
available for investment/engagement in CSR activities. We check for this possibility and find that the coefficient of dividend payout is not statistically significant in a regression where csr is specified as the dependent variable. ${ }^{20}$

\subsection{Alternative Measure of CSR}

We also check for the robustness of our findings by using an alternative measure of csr called csr1. In line with Rakotomavo (2012), we re-estimate the model by using CSR strengths only as an alternative measure of CSR and find that all the regression coefficients are of the same signs and similar magnitudes as in Table 4 and the coefficient of csr1 is still statistically significant at conventional levels in the main equation only. ${ }^{21}$

\subsection{Alternative Measure of Dividend Policy}

Recall that our proxy for dividend policy is dividends paid divided by diluted earnings per share. One may question whether this proxy may be mechanically related to the firm's CSR activities via the earnings channel (i.e., the denominator term of our proxy). We use an alternative proxy of dividend policy instead. This alternative proxy defines dividend policy as the ratio of cash dividends on common stocks to net sales and has been used in many papers (e.g., La Porta et al, 2000; Brockman and Unlu, 2009; Chay and Suh, 2009). We find that with this alternative measure, the main results remain very much the same. ${ }^{22}$

\subsection{Which CSR sub-dimension(s) matters?}

\footnotetext{
${ }^{20}$ Results are available upon request.

${ }^{21}$ Results are available upon request.

${ }^{22}$ Though not reported here, we also use the ratio of cash dividends on common stocks to total assets as another proxy for dividend policy. The results are similar and available upon request.
} 
Note that our CSR measure is an aggregate measure that captures only the overall (average) performance of a firm on seven CSR sub-dimensions. They are community relations, human rights, product safety, corporate governance, diversity, employee relations and the environment. It is interesting to know which of them affect dividend policy. Table 7 shows that out of these seven sub-dimensions, only five of them can explain dividend payout decision because their coefficients are statistically significant at the conventional levels. They (Their coefficient) are the environment (-0.095), community relations (0.376), diversity (0.176), product safety $(-0.481)$, and corporate governance $(0.179)$. Both the environment and product safety dimensions are negatively related to dividend payouts while the remaining three sub-dimensions are positively associated with dividend payouts. ${ }^{23}$ The two most influential dimensions are product safety $(-0.481)$ and community relations $(0.367)$, respectively. These results seem to suggest that investment along some CSR dimensions (community relations, diversity and corporate governance) could put the firm in a better position to pay higher dividends while investment along other dimensions (the environment and product safety) could not probably because the latter investments are too costly for the firm to bear. With this kind of costly investments in place, the firm may experience lower earnings and dividends in the short run. However, when viewed as a whole, the total positive (and significant) impacts $(0.731=0.376+0.176+0.179)$ outweighs the total negative (and significant) impacts $(-0.576=-0.095-0.481)$, resulting in an overall positive impacts of csr on dividend payouts decision. ${ }^{24}$

\footnotetext{
${ }^{23}$ These seven sub-dimensions suffer no serious multicollinearity problem as their correlations are typically less than 0.25 and their variance inflation factor are low (i.e., less than 10).

${ }^{24}$ Note that corporate governance and diversity also affect propensity to pay dividends as well. This result is consistent with one of the main findings that csr does not affect propensity to pay dividends because the impact of corporate governance and diversity are similar in magnitude but opposite in direction, making the net effect of csr upon propensity to pay dividends not different from zero in statistical sense.
} 


\section{Conclusions}

In this paper, we investigate whether CSR affects firms' dividend policy. Two competing views are identified and they have different predictions on the relation between CSR and dividend policy. "The earnings channel" predicts a positive relation because CSR activities can enhance income, putting firms in a better position to pay (higher) dividends. "The cost of equity capital channel" depicts a negative relation because CSR activities can lower the cost of equity capital, which in turns provides incentives for firms to invest or hoard cash rather than to pay dividends.

By using a panel dataset of 1,945 US listed firms from 1991 to 2010, we find that there is no significant relationship between CSR and the propensity to pay dividends. However, firms with higher CSR scores tend to have a higher dividend payout ratio. The decision on whether or not to pay dividends is positively correlated with the decision on what dividends should be paid. These results indicate that overall CSR does not affect firms' decisions on whether to pay dividends but it positively affects their decisions on what dividends to pay. The finding is consistent with the prediction of the earnings channel. Our results are robust to alternative measures of csr and dividend policy, alternative estimation techniques and endogeneity issues. 
Appendix A: Definition of the key variables

\begin{tabular}{|c|c|c|}
\hline Variable & Definition & COMPUSTAT Data Items \\
\hline Systematic risk (beta) & $\begin{array}{l}\text { Beta from the market model on } \\
\text { daily returns over previous } 3 \\
\text { years. }\end{array}$ & Not applicable \\
\hline Book value of equity $\left(B V_{e}\right)$ & $\begin{array}{l}\text { Stockholder's equity - Preferred } \\
\text { stock + Deferred tax and } \\
\text { investment tax credit -Post- } \\
\text { retirement benefits }\end{array}$ & $\begin{array}{l}\text { (SEQ, or CEQ+PSTK, or } \\
\text { AT-LT) - (PSTKL, or } \\
\text { PSTKRV, or PSTK) + } \\
\text { TXDITC - PRBA }\end{array}$ \\
\hline Cash to total assets (cash) & Cash or equivalent/total assets & CHE/AT \\
\hline CSR score (csr) & $\begin{array}{l}\text { Simple average of seven CSR- } \\
\text { dimension net scores (i.e., } \\
\text { strengths - weaknesses) from } \\
\text { the KLD database }\end{array}$ & Not applicable \\
\hline $\begin{array}{l}\text { Alternative measure of CSR } \\
\text { (csr1) }\end{array}$ & $\begin{array}{l}\text { Simple average of seven CSR- } \\
\text { dimension strength scores from } \\
\text { the KLD database }\end{array}$ & Not applicable \\
\hline Earnings to total assets (eta) & Earnings/total assets & NI/AT \\
\hline Idiosyncratic risk (idio) & $\begin{array}{l}\text { Residual variance from the } \\
\text { Fama-French three-factor } \\
\text { model over previous } 3 \text { years. }\end{array}$ & Not applicable \\
\hline IPO post 1990 (ipo90) & $\begin{array}{l}\text { A dummy variable capturing if } \\
\text { IPO date is after } 1990 .\end{array}$ & Not applicable \\
\hline Leverage (lev) & Long-term debt to total assets & DLTT/AT \\
\hline Growth opportunities (mtb) & Market-to-book ratio & $\begin{array}{l}\left(\mathrm{AT}-\mathrm{BV}_{\mathrm{e}}+\mathrm{MV}_{\mathrm{e}}\right) / \mathrm{AT} \\
\text { where } \mathrm{BV}_{\mathrm{e}}=\text { book value } \\
\text { of equity } \\
\mathrm{MV}_{\mathrm{e}}=\text { market value of } \\
\text { equity }\end{array}$ \\
\hline Market value of equity $\left(M V_{e}\right)$ & $\begin{array}{l}\text { Number of shares outstanding } x \\
\text { Share price }\end{array}$ & CSHO $\times$ PRCC_F \\
\hline Market capitalization (nysep) & $\begin{array}{l}\text { Percentile of New York Stock } \\
\text { Exchange to which a firm's } \\
\text { market capitalization belongs }\end{array}$ & Not applicable \\
\hline Payer (payer) & $\begin{array}{l}\text { Dummy variable of whether a } \\
\text { firm paid dividends in the } \\
\text { previous year }\end{array}$ & $\begin{aligned} \text { Payer }_{\mathrm{t}} & =1 \text { if payout } \mathrm{t}-1>0 \\
& =0 \text { if else }\end{aligned}$ \\
\hline $\begin{array}{l}\text { Dividend payout ratio } \\
\text { (payout) }\end{array}$ & $\begin{array}{l}\text { Dividends per share/Fully } \\
\text { Diluted Earnings Per Share }\end{array}$ & DVPSX_F/EPSFX \\
\hline $\begin{array}{l}\text { Retained earnings to assets } \\
\text { (reta) }\end{array}$ & Retained earnings/total assets & RE/AT \\
\hline Redstate (redstate) & $\begin{array}{l}\text { A dummy variable capturing } \\
\text { whether the state in which the } \\
\text { firm's headquarters is/was } \\
\text { located is red (Republican) or } \\
\text { blue (Democratic) state. }\end{array}$ & Not applicable \\
\hline
\end{tabular}




\begin{tabular}{l|l|l}
\hline Cost of equity capital (r_com) & $\begin{array}{l}\text { A composite of five different } \\
\text { measures of cost of capital } \\
\text { based on analysts' earnings } \\
\text { forecasts as proposed by Hou et } \\
\text { al. (2012). }\end{array}$ & \\
\hline Stock buyback (sbuyback) & $\begin{array}{l}\text { Increase in treasury stock or } \\
\text { total expenditure on the } \\
\text { purchase of common and } \\
\text { preferred stocks minus any } \\
\text { reduction in the redemption } \\
\text { value of the net number of } \\
\text { preferred stocks outstanding } \\
\text { (the greater of the difference } \\
\text { between purchases and sales of } \\
\text { common and preferred stock or } \\
\text { zero). }\end{array}$ & \\
\hline Tax regime (taxregime) & $\begin{array}{l}\text { A dummy variable capturing if } \\
\text { there is a dividend tax cut in a }\end{array}$ & \\
& $\begin{array}{l}\text { Particular year (i.e., year }> \\
\text { 2002) }\end{array}$ & \\
\hline
\end{tabular}




\section{Appendix B}

Formally, let $Y$ denote the dependent variable of the main equation of interest (i.e., the dividend payout decision) and $X_{1}$ a vector of the explanatory variables. Moreover, let $S$ denote an indicator variable that is equal to 1 if $Y$ is observed (i.e., non-zero) and 0 otherwise. Given a vector of explanatory variables $X_{2}$, the selection equation (the propensity to pay decision) is given by

$$
S=\left\{\begin{array}{rr}
1 & \text { if } X_{2} \beta_{2}+v>0 \\
0 & \text { otherwise }
\end{array},\right.
$$

where $\beta_{2}$ is a vector of the parameters and $v$ denotes the error term. The dependent variable $Y$ is related to $S$ as follows:

$$
Y=\left\{\begin{array}{ll}
X_{1} \beta_{1}+u & \text { if } S=1 \\
0 & \text { otherwise }
\end{array},\right.
$$

where $\beta_{1}$ is a vector of the parameters and $u$ denotes the error term.

If $u$ and $v$ are correlated, the OLS estimation of the main equation using only the observations with $S=1$ leads to sample selection bias. This is because

$$
E\left[Y \mid X_{1}, X_{2}, S=1\right]=X_{1} \beta_{1}+\gamma \lambda\left(X_{2} \beta_{2}\right)
$$

where $\gamma$ is a parameter and

$$
\lambda\left(X_{2} \beta_{2}\right)=\frac{\phi\left(X_{2} \beta_{2}\right)}{\Phi\left(X_{2} \beta_{2}\right)}
$$

is known as the inverse Mills ratio term. Equation (3) shows that estimating the main equation by using only observations with $S=1$ induces an omitted variable bias problem, as the inverse Mills ratio might be correlated with the explanatory variables $X_{1}$. 
In order to get consistent estimates, one may estimate the main equation by OLS using only observations with $S=1$, but the set of covariates must include not only $X_{1}$ but also the inverse Mills ratio term $\lambda\left(X_{2} \beta_{2}\right)$.

In the presence of the sample selection problem, Heckman (1979) proposes full information maximum likelihood (FIML) and two-step estimators, assuming that the errors in the selection and main equations are jointly normally distributed. These assumptions are theoretically sufficient for identification by exploiting the nonlinearity of the selection bias correction term (i.e., inverse Mills ratio). If the same set of explanatory variables (i.e., $\mathrm{X}_{1}=\mathrm{X}_{2}$ ) is used in both the main and the selection equations, this means that $X_{1}$ (or $X_{2}$ ) can affect $Y_{1}$ directly and indirectly via $\lambda$ in equation (3), making the estimation of equation (3) more susceptible to the multicollinearity problem. To avoid the potential multicollinearity problem, we apply the exclusion restriction that requires the set of variables for $X_{1}$ to be a subset of that for $X_{2}$. More specifically, we include in the set of $X_{2}$ (or equivalently, in the selection equation) three additional variables (ipo90, an interaction variable between reta and ipo90 and taxregime) recently proposed by Banyi and Kahle (2014) as new determinants of the propensity to pay. They report evidence that those firms (especially those young firms) who went IPO after 1990 tend to have a lower propensity to pay dividends and that the propensity to pay is also lower in tax regimes where there are dividend tax cuts. 


\section{References}

Akyildirim, E., E. Guney, J. Rochet, and M. Soner, 2014, Optimal dividend policy with random interest rates, Journal of Mathematical Economics 51, 93-101.

Albuquerque, R., A. Durnev, and Y. Koskinen, 2014, Corporate social responsibility and firm risk: theory and empirical Evidence, SSRN Working Paper.

Arouri, M., G. Pijourlet, 2015, CSR performance and the value of cash holdings: international evidence, Journal of Business Ethic, doi: 10.1007/s10551-015-2658-5.

Banyi, M., and K. Kahle, 2014, Declining propensity to pay? A re-examination of the lifecycle theory. Journal of Corporate Finance 27, 345-366.

Baron, D., 2001, Private politics, corporate social responsibility, and integrated strategy, Journal of Economics \& Management Strategy 10(1), 7-45.

Brockman, P., and E. Unlu, 2009, Dividend policy, creditor rights, and the agency cost of debt, Journal of Financial Economics 92, 276-299.

Chatterji, A., D. Levine, and M. Toffel, 2009, How well do social ratings actually measure corporate social responsibility? Journal of Economics and Management Strategy 18, 125169.

Chay, J., and J. Suh, 2009, Payout policy and cash-flow uncertainty, Journal of Financial Economics 93, 88-107.

Cheung, A., 2016, Corporate social responsibility and corporate cash holdings, Journal of Corporate Finance 37, 412-430.

Choi, J., and H. Wang, 2009, Stakeholder relations and the persistence of corporate social performance, Strategic Management Journal 30, 895-907.

Deng, X., J. Kang, and B. Low, 2013, Corporate social responsibility and stakeholder value maximization: evidence from mergers, Journal of Financial Economics 110, 87- 
109.DeAngelo, H., L. DeAngelo, and D. Skinner, 2004, Are dividends disappearing? Dividend concentration and the consolidation of earnings, Journal of Financial Economics 72, 425456.

DeAngelo, H., L. DeAngelo, and R. Stulz, 2006, Dividend policy and the earned/contributed capital mix: a test of the life-cycle theory, Journal of Financial Economics 81, 227-254.

Derwall, J., and P. Verwijmeren, 2007, CSR and the cost of equity capital. In Derwall, Jeroen (ed.) The Economic Virtues of SRI and CSR. Haveka, 193-213.

Dhaliwal, D. O. Li, A. Tsang, and Y. Yang, 2011, Voluntary non-financial disclosure and the cost of equity capital: the case of corporate social responsibility reporting, The Accounting Review 86, 59-100.

Di Giuli, A., and L. Kostovetsky, 2014, Are red or blue companies more likely to go Green? Politics and corporate social responsibility. Journal of Financial Economics 111, 158-180.

Dustmann, C., and M. Rochina-Barrachina, 2007, Selection correction in panel data models: an application to the estimation of females' wage equations, Econometrics Journal 10, 263293.

Fabrizi, M., C. Mallin, and G. Michelon, 2014, The role of CEO's personal incentives in driving corporate social responsibility. Journal of Business Ethics 124, 311-326.

Fama, E., and K. French, 2001, Disappearing dividends: changing firm characteristics or lower propensity to pay? Journal of Financial Economics 60, 3-43.

Fama, E., and K. French, 2002, Testing trade-off and pecking order predictions about dividends and debt. Review of Financial Studies 15, 1-33.

Garcia-Castro, R., M. Ariño, and M. Canela, 2010, Does social performance really lead to financial performance? Accounting for endogeneity. Journal of Business Ethics 92(1), 107126. 
Ghoul, S., O. Guedhami, C. Kwok, and D. Mishra, 2011, Does corporate social responsibility affect the cost of capital? Journal of Banking \& Finance 35, 2388-2406.

Godfrey, P., C. Merrill, and J. Hansen, 2009, The relationship between CSR and shareholder value: an empirical test of the risk management hypothesis. Strategic Management Journal 30, 425-455.

Goss, A., and G. Roberts, 2011, The impact of corporate social responsibility on the cost of bank loans, Journal of Banking \& Finance 35, 1794-1810.

Gregory, A., J. Whittaker, and X. Yan, 2011, Do markets value corporate social responsibility? Griffith Law Review 20, 221-244.

Gul, F., 1999, Growth opportunities, capital structure and dividend policies in Japan, Journal of Corporate Finance 5(2), 141-168.

Harjoto, M., and H. Jo, 2011, Corporate governance and CSR nexus, Journal of Business Ethics 100(1), 45-67.

Hart, S., and G. Ahuja, 1996, Does it pay to be green? An empirical examination of the relationship between emission reduction and firm performance, Business Strategy and the Environment 5, 30-7.

Heal, G., 2005, Corporate social responsibility: an economic and financial framework, The Geneva Papers 30(3), 387-409.

Heckman, J., 1979, Sample selection bias as a specification error, Econometrica 47(1), 153161.

Hillman, A., and G. Keim, 2001, Shareholder value, stakeholder management, and social issues: What's the bottom line? Strategic Management Journal 22(2), 125-139.

Hoberg, G., and N. Prabhala, 2009, Disappearing dividends, catering and risk. Review of Financial Studies 22(1), 79-116. 
Hong, H., and M. Kacperczyk, 2009, The price of sin: the effects of social norms on markets. Journal of Financial Economics 93(1), 15-36.Hou, K., M. Van Dijk, and Y. Zhang, 2012, The implied cost of capital: a new approach. Journal of Accounting and Economics 53, 504-526. Jensen, M., 1986, Agency costs of free cash flow, corporate finance, and takeovers. American Economic Review 76(2), 323-329.

Jiraporn, P., and P. Chintrakarn, 2013, How do powerful CEOs view corporate social responsibility (CSR)? An empirical note. Economics Letters 119, 344-347.

Jo, H., and H. Na, 2012, Does CSR reduce firm risk? Evidence from controversial industry sectors. Journal of Business Ethics 110(4), 441-456.

Johnston, A., 2010, Facing up to social cost: the real meaning of corporate social responsibility. SSRN Working Paper.

Jones, T., 1995, Instrumental stakeholder theory: A synthesis of ethics and economics, Academy of Management Review 20(2), 404-437.

Kempf, A., and P. Osthoff, 2007, The effect of socially responsible investing on portfolio performance, European Financial Management 13(5), 908-922.

Kim, C., D. Mauer, A. Sherman, 1998, The determinants of corporate liquidity: Theory and evidence. Journal of Financial and Quantitative Analysis 33(3), 335-359.

Kyriazidou, E., 1997, Estimation of a panel data sample selection model. Econometrica 65, $1335-1364$.

La Porta, R., F. Lopez-de-Silanes, A. Shleifer, and R. Vishny, 2000, Agency problems and dividend policies around the world, Journal of Finance 55, 1-33.

Luo, X., and C. Bhattacharya, 2009, The debate over doing good: corporate social performance, strategic marketing levers, and firm-idiosyncratic risk. Journal of Marketing 73, 198-213. 
Manescu, C., 2011, Stock returns in relation to environmental, social and governance performance: mispricing or compensation for risk? Sustainable Development, John Wiley \& Sons, Ltd., 19(2), 95-118.

Manescu, C., and S. Catalin, 2007, The relevance of corporate social responsibility scores in explaining firm profitability: a case study of the publishers of the Dow Jones Sustainability Indexes, Centre for Finance, Université de Neuchâtel.

Margolis, J., H. Elfenbein, and J. Walsh, 2009, Does it pay to be good ... and does it matter? A meta-analysis and redirection of research on the relationship between corporate social and financial performance, SSRN Working paper.

Menz, K., 2010, Corporate social responsibility: is it rewarded by the corporate bond market? A critical note, Journal of Business Ethics 96, 117-134.

Michaely, R., and M. Roberts, 2012, Corporate dividend policies; Lessons from private firms. Review of Financial Studies 25(3), 711-746.

Min, Y., and A. Agresti, 2002, Modelling nonnegative data with clumping at zero: a survey, Journal of Iranian Statistical Society 1, 7-33.

Myers, S., 1984, The capital structure puzzle. Journal of Finance 28, 575-592.

Nelsen, R., 2006, An Introduction to Copulas, $2^{\text {nd }}$ edition, Springer. New York.

Orlitzky, M., F. Schmidt, and S. Rynes, 2003, Corporate social and financial performance: a meta-analysis, Organization Studies 24, 403-441.

Phillips, P., and D. Sul, 2007, Bias in dynamic panel estimation with fixed effects, incidental trends and cross section dependence, Journal of Econometrics 137(1), 162-188.

Porter, M., and M. Kramer, 2006, Strategy \& society: the link between competitive advantage and corporate social responsibility, Harvard Business Review 84(12), 78- 
92.Rakotomavo, M., 2012, Corporate investment in social responsibility versus dividends? Social Responsibility Journal 8, 199-207.

Rochina-Barrachina, M., 1999, A new estimator for panel data sample selection models, Annales d'Economie et de Statistique 55/56, 153-181.

Schwiebert, J., 2015, Estimation and Interpretation of a Heckman Selection Model with Endogenous Covariates. Empirical Economics 49, 675-703.

Semykina, A., and J. Wooldridge, 2010, Estimating Panel Data Models in the Presence of Endogeneity and Selection, Journal of Econometrics 157, 375-380.

Sharfman, M., and C. Fernando, 2008, Environmental risk management and the cost of capital, Strategic Management Journal 29, 569-92.

Siegel, D., and D Vitaliano,, 2007, An empirical analysis of the strategic use of corporate social responsibility, Journal of Economics \& Management Strategy 16, 773-792.

Smith, M., 2003, Modelling sample selection using Archimedean copulas, Econometrics Journal 6(1), 99-123.

Staiger, D., and J. Stock, 1997, Instrumental variables regression with weak instruments, Econometrica 65, 557-586.

Statman, M., 2000, Socially responsible mutual funds, Financial Analysts Journal 56(3), 3039.

Stock, J., and M. Yogo, 2005, Testing for weak instruments in linear IV regression. In Identification and Inference for Econometric Models: Essays in Honor of Thomas Rothenberg, ed. Donald W. K. Andrews and James H. Stock, 80-108. Cambridge: Cambridge University Press.

Surroca, J., and J. Tribo, 2008, Managerial entrenchment and corporate social performance, Journal of Business Finance \& Accounting 35, 748-789. 
Vitaliano, D., 2010, Corporate social responsibility and labor turnover, Corporate Governance: The International Journal of Business in Society 10(5), 563-573.

Wang, Q., J. Dou, and S. Jie, 2015, A meta-analytic review of corporate social responsibility and corporate financial performance: The moderating effect of contextual factors, Business \& Society doi: $10.1177 / 0007650315584317$.

Wooldridge, J., 1995, Selection corrections for panel data models under conditional mean independence assumptions, Journal of Econometrics 68, 115-132.

Zuehlke, T., and A. Zeman, 1991, A comparison of two-stage estimators of censored regression models, The Review of Economics and Statistics 73(1), 185-188. 
Table 1: No. of firms across years

\begin{tabular}{|c|c|c|c|}
\hline Year & $\mathrm{N}(\text { effective } \mathrm{N})^{*}$ & $\%^{* *}$ & Cum $\%{ }^{* *}$ \\
\hline 1991 & $327(269)$ & 1.73 & 1.73 \\
\hline 1992 & $330(265)$ & 1.70 & 3.43 \\
\hline 1993 & $337(290)$ & 1.86 & 5.30 \\
\hline 1994 & $338(291)$ & 1.87 & 7.17 \\
\hline 1995 & $348(312)$ & 2.01 & 9.17 \\
\hline 1996 & $362(323)$ & 2.08 & 11.25 \\
\hline 1997 & $365(325)$ & 2.09 & 13.33 \\
\hline 1998 & $374(306)$ & 1.97 & 15.30 \\
\hline 1999 & $384(332)$ & 2.13 & 17.43 \\
\hline 2000 & $403(354)$ & 2.27 & 19.71 \\
\hline 2001 & $685(515)$ & 3.31 & 23.02 \\
\hline 2002 & $689(600)$ & 3.86 & 26.87 \\
\hline 2003 & $1,836(1,241)$ & 7.98 & 34.85 \\
\hline 2004 & $1,964(1,369)$ & 8.80 & 43.65 \\
\hline 2005 & $1,915(1,444)$ & 9.28 & 52.93 \\
\hline 2006 & $1,939(1,491)$ & 9.58 & 62.51 \\
\hline 2007 & $1,909(1,469)$ & 9.44 & 71.95 \\
\hline 2008 & $1,980(1,471)$ & 9.45 & 81.40 \\
\hline 2009 & $2,042(1,454)$ & 9.34 & 90.75 \\
\hline 2010 & $2,087(1,440)$ & 9.25 & 100.00 \\
\hline Total & $20,614(15,561)$ & 100.00 & 100.00 \\
\hline \multicolumn{4}{|c|}{$\begin{array}{l}\text { This table reports the number of sample observations }(\mathrm{N}) \text { across years. } \\
\text { *Effective } N \text { refers to the actual no. of observations used in estimation; } \\
\text { it is not the same as } N \text { because the construction of a control variable } \\
\text { called "cost of equity capital" requires analyst earnings forecasts which } \\
\text { are not available for a substantial portion of the sample firms. } \\
\text { *^ Percentage and cumulative percentage refer to those percentages for } \\
\text { the effective sample firms only. }\end{array}$} \\
\hline
\end{tabular}

Table 2: Transition probabilities (in percentage)

\begin{tabular}{lccc}
\hline & Don't pay & Pay & total \\
\hline Don't pay & 91.83 & 8.17 & 100.00 \\
Pay & 7.39 & 92.61 & 100.00 \\
total & 51.17 & 48.83 & \\
\hline
\end{tabular}

This table reports the transition probabilities (in percentage) of a firm going from a given state to next state. 
Table 3: Summary Statistics of the Key Variables

\begin{tabular}{lrrrrrrrrrrrrrr}
\hline Panel A & payout & \multicolumn{1}{c}{ csr } & \multicolumn{1}{c}{ csr1 } & nysep & \multicolumn{1}{c}{ mtb } & \multicolumn{1}{c}{ lev } & eta & r_com & beta & idio & sbuyback & payer & cash & reta \\
\hline mean & 0.152 & -0.013 & 0.246 & 43.403 & 2.160 & 0.214 & 0.058 & 0.136 & 1.162 & 2.353 & 0.012 & 0.443 & 0.189 & -0.074 \\
std. dev. & 0.254 & 0.075 & 0.369 & 30.268 & 1.657 & 0.216 & 0.046 & 0.144 & 0.523 & 1.160 & 0.060 & 0.497 & 0.212 & 1.607 \\
skewness & 1.912 & 0.239 & 2.845 & 0.214 & 5.308 & 2.526 & 0.812 & 2.038 & 0.757 & 2.342 & -2.627 & 0.228 & 1.541 & -13.717 \\
kurtosis & 6.064 & 8.918 & 14.420 & 1.686 & 81.792 & 22.434 & 27.720 & 9.169 & 4.559 & 15.487 & 211.817 & 1.052 & 4.842 & 334.608 \\
\hline
\end{tabular}

\begin{tabular}{lrrrr}
\hline Panel B & ipo90 & reta*ipo90 & taxregime & redstate \\
\hline mean & 0.489 & -0.209 & 0.760 & 0.297 \\
std. dev. & 0.500 & 1.503 & 0.427 & 0.457 \\
skewness & 0.044 & -15.808 & -1.219 & 0.889 \\
kurtosis & 1.002 & 422.464 & 2.487 & 1.791 \\
\hline
\end{tabular}

This table shows the summary statistics of the key variables used in

this paper. Panel A shows those variables used in dividend payout

decision, where Panel $B$ shows additional variables used in propensity

to pay dividends decision. For variable definitions see Appendix $A$ 
Table 4: Parameter estimates for the Heckman sample selection model

\begin{tabular}{|c|c|c|c|c|}
\hline VARIABLES & $\begin{array}{c}(1) \\
\text { Two-step } \\
\text { main }\end{array}$ & $\begin{array}{c}\text { (2) } \\
\text { Two-step } \\
\text { selection }\end{array}$ & $\begin{array}{c}(3) \\
\text { FIML^ }^{\wedge} \\
\text { main }\end{array}$ & $\begin{array}{c}(4) \\
\text { FIML^}^{\wedge} \\
\text { selection }\end{array}$ \\
\hline intercept & $\begin{array}{c}-2.607^{\star \star \star} \\
(0.17)\end{array}$ & $\begin{array}{c}-1.055^{\star \star \star} \\
(0.11)\end{array}$ & $\begin{array}{c}-1.525^{\star \star \star} \\
(0.09)\end{array}$ & $\begin{array}{c}-1.084^{\star \star \star} \\
(0.11)\end{array}$ \\
\hline $\operatorname{csr}$ & $\begin{array}{c}0.237^{\star \star} \\
(0.12)\end{array}$ & $\begin{array}{l}0.194 \\
(0.23)\end{array}$ & $\begin{array}{c}0.269^{\star \star \star} \\
(0.10)\end{array}$ & $\begin{array}{l}0.214 \\
(0.22)\end{array}$ \\
\hline nysep & $\begin{array}{c}-0.001^{\star \star \star} \\
(0.00)\end{array}$ & $\begin{array}{c}0.005^{\star \star \star} \\
(0.00)\end{array}$ & $\begin{array}{c}-0.002^{\star \star \star} \\
(0.00)\end{array}$ & $\begin{array}{c}0.005^{\star \star \star} \\
(0.00)\end{array}$ \\
\hline$m t b$ & $\begin{array}{l}0.012 \\
(0.01)\end{array}$ & $\begin{array}{l}0.011 \\
(0.02)\end{array}$ & $\begin{array}{l}0.013 \\
(0.01)\end{array}$ & $\begin{array}{l}0.011 \\
(0.02)\end{array}$ \\
\hline lev & $\begin{array}{c}0.436 \text { *** } \\
(0.08)\end{array}$ & $\begin{array}{c}-0.294^{\star \star \star} \\
(0.11)\end{array}$ & $\begin{array}{c}0.515^{\star \star \star} \\
(0.07)\end{array}$ & $\begin{array}{c}-0.298^{\star *} \\
(0.13)\end{array}$ \\
\hline eta & $\begin{array}{l}0.323 \\
(0.22)\end{array}$ & $\begin{array}{l}0.578 \\
(0.42)\end{array}$ & $\begin{array}{c}0.354^{*} \\
(0.19)\end{array}$ & $\begin{array}{c}0.669 * \\
(0.41)\end{array}$ \\
\hline r_com & $\begin{array}{c}0.486^{\star \star \star} \\
(0.17)\end{array}$ & $\begin{array}{c}-3.691^{\star \star \star} \\
(0.20)\end{array}$ & $\begin{array}{c}1.106^{\star \star \star} \\
(0.14)\end{array}$ & $\begin{array}{c}-3.689 * \star \star \\
(0.21)\end{array}$ \\
\hline beta & $\begin{array}{c}-0.383^{\star \star \star} \\
(0.02)\end{array}$ & $\begin{array}{c}-0.126^{\star \star *} \\
(0.04)\end{array}$ & $\begin{array}{c}-0.376^{\star \star \star} \\
(0.02)\end{array}$ & $\begin{array}{c}-0.131^{\star \star \star} \\
(0.04)\end{array}$ \\
\hline idio & $\begin{array}{c}-0.213^{\star \star \star} \\
(0.02)\end{array}$ & $\begin{array}{c}-0.341^{\star \star \star} \\
(0.02)\end{array}$ & $\begin{array}{c}-0.126^{\star \star \star} \\
(0.02)\end{array}$ & $\begin{array}{c}-0.340 \star \star \star \\
(0.03)\end{array}$ \\
\hline sbuyback & $\begin{array}{c}-0.625^{\star \star \star} \\
(0.17)\end{array}$ & $\begin{array}{l}0.167 \\
(0.30)\end{array}$ & $\begin{array}{c}-0.633^{\star \star \star} \\
(0.14)\end{array}$ & $\begin{array}{l}0.161 \\
(0.29)\end{array}$ \\
\hline payer & $\begin{array}{c}1.899 \star \star \star \\
(0.18)\end{array}$ & $\begin{array}{c}2.926^{\star \star \star} \\
(0.04)\end{array}$ & $\begin{array}{c}0.732^{\star \star \star} \\
(0.07)\end{array}$ & $\begin{array}{c}2.930 \star \star \star \\
(0.05)\end{array}$ \\
\hline cash & $\begin{array}{c}0.261^{\star \star \star} \\
(0.10)\end{array}$ & $\begin{array}{c}-0.508^{\star \star \star} \\
(0.14)\end{array}$ & $\begin{array}{c}0.320^{\star * *} \\
(0.10)\end{array}$ & $\begin{array}{c}-0.519 \star \star \star \star \\
(0.14)\end{array}$ \\
\hline reta & $\begin{array}{c}-0.074^{\star \star} \\
(0.04)\end{array}$ & $\begin{array}{c}0.845^{\star \star \star} \\
(0.09)\end{array}$ & $\begin{array}{c}-0.165^{\star \star \star} \\
(0.03)\end{array}$ & $\begin{array}{c}0.839 * * \star \\
(0.10)\end{array}$ \\
\hline ipo90 & & $\begin{array}{c}0.084^{*} \\
(0.05)\end{array}$ & & $\begin{array}{l}0.084 \\
(0.06)\end{array}$ \\
\hline reta*ipo90 & & $\begin{array}{c}-0.762^{\star \star \star} \\
(0.10)\end{array}$ & & $\begin{array}{c}-0.746^{\star \star \star} \\
(0.13)\end{array}$ \\
\hline taxregime & & $\begin{array}{c}0.409 * \star * \\
(0.05)\end{array}$ & & $\begin{array}{c}0.432^{\star \star \star} \\
(0.05)\end{array}$ \\
\hline mills & $\begin{array}{c}0.740 * \star \star \\
(0.10)\end{array}$ & & & \\
\hline rho & & & $\begin{array}{c}0.107^{\star \star \star} \\
(0.02)\end{array}$ & \\
\hline Observations & & & & 15,561 \\
\hline Censored observations & & & & 8,269 \\
\hline Log Likelihood & & & & $-12,261$ \\
\hline Wald test of independence ( $p$-value) & & & & $20.87(0.000)$ \\
\hline \multicolumn{5}{|c|}{$\begin{array}{l}\text { This table reports results for the Heckman sample selection model where there are two equations called main } \\
\text { equation and selection equation, respectively. The dependent variable In the main (selection) equation is } \\
\text { dividend payout ratio (propensity to pay dividends) (see Appendix B). Two estimation methods are used and they } \\
\text { are two-step estimation (Columns (1) and (2)) and full information maximum likelihood (FIML) estimation } \\
\text { (Columns (3) and (4)). For variable definitions see Appendix A. Standard errors are reported in parentheses; *, ** } \\
\text { and *** represent significance at the } 10 \text { percent, } 5 \text { percent and } 1 \text { percent level, respectively. } \\
\wedge \text { Robust standard errors are reported for FIML estimates only. }\end{array}$} \\
\hline
\end{tabular}


Table 5: Parameter estimates for the Heckman sample selection model with copula dependence

\begin{tabular}{|c|c|c|}
\hline VARIABLES & $\begin{array}{c}(1) \\
\text { main }\end{array}$ & $\begin{array}{c}(2) \\
\text { selection }\end{array}$ \\
\hline intercept & $\begin{array}{c}-2.174^{\star \star \star} \\
(0.11)\end{array}$ & $\begin{array}{c}-2.184^{\star \star \star} \\
(0.21)\end{array}$ \\
\hline csrnet & $\begin{array}{c}0.226 \star \star \star \star \\
(0.09)\end{array}$ & $\begin{array}{l}0.561 \\
(0.43)\end{array}$ \\
\hline nysep & $\begin{array}{c}-0.001^{\star \star \star} \\
(0.00)\end{array}$ & $\begin{array}{c}0.011^{\star \star \star} \\
(0.00)\end{array}$ \\
\hline$m t b$ & $\begin{array}{l}0.002 \\
(0.01)\end{array}$ & $\begin{array}{l}0.025 \\
(0.03)\end{array}$ \\
\hline lev & $\begin{array}{c}0.625^{\star \star \star} \\
(0.07)\end{array}$ & $\begin{array}{c}-0.488^{\star \star} \\
(0.24)\end{array}$ \\
\hline eta & $\begin{array}{c}0.427^{\star \star} \\
(0.18)\end{array}$ & $\begin{array}{c}1.817^{\star \star} \\
(0.83)\end{array}$ \\
\hline r_com & $\begin{array}{c}1.059 \star \star \star \star \\
(0.13)\end{array}$ & $\begin{array}{c}-7.404^{\star \star \star} \\
(0.41)\end{array}$ \\
\hline beta & $\begin{array}{c}-0.385^{\star \star \star} \\
(0.02)\end{array}$ & $\begin{array}{c}-0.311^{\star \star \star} \\
(0.08)\end{array}$ \\
\hline idio & $\begin{array}{c}-0.145^{\star \star \star} \\
(0.01)\end{array}$ & $\begin{array}{c}-0.627^{\star \star \star} \\
(0.04)\end{array}$ \\
\hline sbuyback & $\begin{array}{c}-0.820 * \star \star \\
(0.15)\end{array}$ & $\begin{array}{l}0.108 \\
(0.56)\end{array}$ \\
\hline payer & $\begin{array}{c}1.389 * * * \\
(0.10)\end{array}$ & $\begin{array}{c}5.356^{\star \star \star} \\
(0.10)\end{array}$ \\
\hline cash & $\begin{array}{c}-0.053 \\
(0.04)\end{array}$ & $\begin{array}{c}-1.051^{\star \star \star} \\
(0.27)\end{array}$ \\
\hline reta & $\begin{array}{c}0.309 * * * \\
(0.10)\end{array}$ & $\begin{array}{c}1.617^{\star \star \star} \\
(0.19)\end{array}$ \\
\hline ipo90 & & $\begin{array}{l}0.115 \\
(0.11)\end{array}$ \\
\hline reta*ipo90 & & $\begin{array}{c}-1.208^{\star \star *} \\
(0.28)\end{array}$ \\
\hline taxregime & & $\begin{array}{c}0.968^{\star \star \star} \\
(0.10)\end{array}$ \\
\hline mills & $\begin{array}{c}1.339 * \star \star \\
(0.05)\end{array}$ & \\
\hline Observations & & 15,561 \\
\hline Log Likelihood & & $-12,261$ \\
\hline Wald test of independence ( $p$-value) & & $47.533(0.000)$ \\
\hline
\end{tabular}

This table reports results for the Heckman sample selection model with copula dependence. This model relaxes the joint normality assumption used in Table 4 where there are two equations called main equation and selection equation, respectively. The dependent variable In the main (selection) equation is dividend payout ratio (propensity to pay dividends) (see Appendix B). Full information maximum likelihood (FIML) estimation is used and the estimation results are shown in Columns (1) and (2). For variable definitions see Appendix A. Robust standard errors are reported in parentheses; * ${ }^{* *}$ and ${ }^{* \star *}$ represent significance at the 10 percent, 5 percent and 1 percent level, respectively. 
Table 6: FIML estimation of the Heckman sample selection model with endogenous csr

\begin{tabular}{|c|c|c|c|}
\hline VARIABLES & $\begin{array}{c}(1) \\
\text { main }\end{array}$ & $\begin{array}{c}(2) \\
\text { selection }\end{array}$ & $\begin{array}{c}(3) \\
\text { 1st stage }\end{array}$ \\
\hline intercept & $\begin{array}{c}-1.762^{\star \star \star} \\
(0.23)\end{array}$ & $\begin{array}{c}-0.844^{\star \star} \\
(0.35)\end{array}$ & $\begin{array}{c}0.037^{\star \star *} \\
(0.01)\end{array}$ \\
\hline $\operatorname{csr}$ & $\begin{array}{c}8.887^{\star \star \star} \\
(2.97)\end{array}$ & $\begin{array}{r}-5.952 \\
(5.77)\end{array}$ & \\
\hline redstate & & & $\begin{array}{c}-0.008^{\star \star \star} \\
(0.00)\end{array}$ \\
\hline nysep & $\begin{array}{l}0.001 \\
(0.02)\end{array}$ & $\begin{array}{l}0.000 \\
(0.00)\end{array}$ & $\begin{array}{c}-0.001^{\star \star \star} \\
(0.00)\end{array}$ \\
\hline$m t b$ & $\begin{array}{c}-0.044^{\star \star} \\
(0.02)\end{array}$ & $\begin{array}{l}0.032 \\
(0.04)\end{array}$ & $\begin{array}{c}0.006^{\star \star \star} \\
(0.00)\end{array}$ \\
\hline lev & $\begin{array}{c}0.500^{\star \star \star} \\
(0.09)\end{array}$ & $\begin{array}{c}-0.312^{\star \star} \\
(0.14)\end{array}$ & $\begin{array}{c}-0.008^{\star \star} \\
(0.00)\end{array}$ \\
\hline eta & $\begin{array}{c}-1.904^{\star \star \star} \\
(0.49)\end{array}$ & $\begin{array}{c}5.835^{\star \star *} \\
(0.95)\end{array}$ & $\begin{array}{l}0.032 \\
(0.03)\end{array}$ \\
\hline r_com & $\begin{array}{c}2.464^{\star \star \star} \\
(0.21)\end{array}$ & $\begin{array}{c}-5.126^{\star * *} \\
(0.32)\end{array}$ & $\begin{array}{c}-0.030 * \star \star \\
(0.01)\end{array}$ \\
\hline beta & $\begin{array}{c}-0.146^{\star \star \star} \\
(0.04)\end{array}$ & $\begin{array}{c}-0.128^{\star \star} \\
(0.06)\end{array}$ & $\begin{array}{c}-0.004^{\star \star \star} \\
(0.00)\end{array}$ \\
\hline idio & $\begin{array}{c}-0.191^{\star \star \star} \\
(0.02)\end{array}$ & $\begin{array}{c}-0.415^{\star \star *} \\
(0.04)\end{array}$ & $\begin{array}{l}0.000 \\
(0.00)\end{array}$ \\
\hline sbuyback & $\begin{array}{c}-0.369 \star \star \\
(0.16)\end{array}$ & $\begin{array}{l}0.057 \\
(0.29)\end{array}$ & $\begin{array}{l}-0.002 \\
(0.01)\end{array}$ \\
\hline payer & $\begin{array}{c}0.529 * \star \star \\
(0.07)\end{array}$ & $\begin{array}{c}2.939 * * * \\
(0.05)\end{array}$ & $\begin{array}{l}-0.000 \\
(0.00)\end{array}$ \\
\hline cash & $\begin{array}{c}0.606^{\star \star \star} \\
(0.11)\end{array}$ & $\begin{array}{c}-0.196 \\
(0.16)\end{array}$ & $\begin{array}{l}0.004 \\
(0.00)\end{array}$ \\
\hline reta & $\begin{array}{c}-0.262^{\star \star \star} \\
(0.04)\end{array}$ & $\begin{array}{c}0.867^{\star \star \star} \\
(0.16)\end{array}$ & $\begin{array}{c}0.021^{\star \star *} \\
(0.00)\end{array}$ \\
\hline ipo90 & & $\begin{array}{l}0.073 \\
(0.07)\end{array}$ & $\begin{array}{c}0.005^{\star \star \star} \\
(0.00)\end{array}$ \\
\hline reta*ipo90 & & $\begin{array}{c}-0.828^{\star * *} \\
(0.16)\end{array}$ & $\begin{array}{c}-0.019 * \star * \\
(0.00)\end{array}$ \\
\hline taxregime & & $\begin{array}{l}0.378 \\
(0.14)\end{array}$ & $\begin{array}{l}0.005 \\
(0.01)\end{array}$ \\
\hline eps & $\begin{array}{c}-9.122^{\star \star \star} \\
(2.98)\end{array}$ & $\begin{array}{c}6.318^{\star \star \star} \\
(5.77)\end{array}$ & \\
\hline industry dummies + year dummies & Yes & Yes & Yes \\
\hline rho & & & $\begin{array}{c}0.055^{\star \star} \\
(0.02)\end{array}$ \\
\hline 1st stage F-statistic & & & 23.136 \\
\hline Observations & & & 15,517 \\
\hline Log Likelihood & & & $7,136.05$ \\
\hline $\begin{array}{l}\text { This table reports results for the He } \\
\text { (2013) we use an instrument called } \\
\text { least squares estimation, where th } \\
\text { located in a red (Republican) state } \\
\text { used and the estimation results are } \\
\text { results. For variable definitions see } \\
\text { represent significance at the } 10 \text { perc }\end{array}$ & $\begin{array}{l}\text { with endos } \\
\text { os in the } \\
\text { dstate, equ } \\
\text { on maximu } \\
\text { Column (3 } \\
\text { rors are rep } \\
\text { el, respecti }\end{array}$ & $\begin{array}{l}\text { IS csr. Foll } \\
\text {-stage regr } \\
1 \text { if a firm' } \\
\text { elihood (FI } \\
\text { ws the first } \\
\text { I in parenth }\end{array}$ & $\begin{array}{l}\text { ng Deng et al. } \\
\text { ion of } 2 \text { stage } \\
\text { eadquarters is } \\
\text { estimation is } \\
\text { age regression } \\
\text {; *, ** and *** }\end{array}$ \\
\hline
\end{tabular}


Table 7: Parameter estimation for the Heckman sample selection model with 7 CSR subdimensions (community relations, corporate governance, diversity, environment, employee relations, the environment, human rights and product safety)

\begin{tabular}{|c|c|c|c|c|}
\hline VARIABLES & $\begin{array}{c}(1) \\
\text { Two-step } \\
\text { main }\end{array}$ & $\begin{array}{c}\text { (2) } \\
\text { Two-step } \\
\text { selection }\end{array}$ & 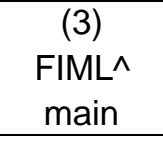 & $\begin{array}{c}(4) \\
\text { FIML^}^{\wedge} \\
\text { selection }\end{array}$ \\
\hline intercept & $\begin{array}{c}-2.526^{\star \star \star} \\
(0.17)\end{array}$ & $\begin{array}{c}-1.074^{\star \star \star} \\
(0.11)\end{array}$ & $\begin{array}{c}-1.512^{\star \star \star} \\
(0.09)\end{array}$ & $\begin{array}{c}-1.102^{\star \star \star} \\
(0.11)\end{array}$ \\
\hline community_relations & $\begin{array}{c}0.376^{\star \star \star} \\
(0.08)\end{array}$ & $\begin{array}{c}-0.218 \\
(0.15)\end{array}$ & $\begin{array}{c}0.427^{\star \star \star *} \\
(0.06)\end{array}$ & $\begin{array}{l}0.206 \\
(0.16)\end{array}$ \\
\hline governance & $\begin{array}{c}0.179 * * * \\
(0.04)\end{array}$ & $\begin{array}{c}0.199 * * * \\
(0.07)\end{array}$ & $\begin{array}{c}0.170 \star \star \star \\
(0.03)\end{array}$ & $\begin{array}{c}0.201^{\star \star \star} \\
(0.06)\end{array}$ \\
\hline diversity & $\begin{array}{c}0.176^{\star \star \star} \\
(0.05)\end{array}$ & $\begin{array}{c}-0.246^{\star \star \star} \\
(0.09)\end{array}$ & $\begin{array}{c}0.204^{\star * *} \\
(0.04)\end{array}$ & $\begin{array}{c}0.249 * \star \star \\
(0.09)\end{array}$ \\
\hline environment & $\begin{array}{c}-0.095^{\star} \\
(0.06)\end{array}$ & $\begin{array}{l}0.060 \\
(0.11)\end{array}$ & $\begin{array}{c}-0.106^{\star *} \\
(0.05)\end{array}$ & $\begin{array}{l}0.052 \\
(0.11)\end{array}$ \\
\hline employee_relations & $\begin{array}{l}0.063 \\
(0.06)\end{array}$ & $\begin{array}{l}-0.021 \\
(0.11)\end{array}$ & $\begin{array}{l}0.071 \\
(0.06)\end{array}$ & $\begin{array}{l}-0.009 \\
(0.11)\end{array}$ \\
\hline human_rights & $\begin{array}{l}0.087 \\
(0.17)\end{array}$ & $\begin{array}{l}0.435 \\
(0.36)\end{array}$ & $\begin{array}{l}0.036 \\
(0.11)\end{array}$ & $\begin{array}{l}0.440 \\
(0.31)\end{array}$ \\
\hline product_safety & $\begin{array}{c}-0.481^{\star \star \star} \\
(0.06)\end{array}$ & $\begin{array}{l}0.155 \\
(0.11)\end{array}$ & $\begin{array}{c}-0.489^{* * *} \\
(0.05)\end{array}$ & $\begin{array}{l}0.165 \\
(0.12)\end{array}$ \\
\hline nysep & $\begin{array}{c}-0.002^{\star \star \star} \\
(0.00)\end{array}$ & $\begin{array}{c}0.006^{\star \star *} \\
(0.00)\end{array}$ & $\begin{array}{c}-0.002^{\star \star \star} \\
(0.00)\end{array}$ & $\begin{array}{c}0.006^{\star \star *} \\
(0.00)\end{array}$ \\
\hline$m t b$ & $\begin{array}{l}0.013 \\
(0.01)\end{array}$ & $\begin{array}{r}0.011 \\
(0.02)\end{array}$ & $\begin{array}{l}0.013 \\
(0.01)\end{array}$ & $\begin{array}{l}0.010 \\
(0.02)\end{array}$ \\
\hline lev & $\begin{array}{c}0.415^{\star \star \star} \\
(0.07)\end{array}$ & $\begin{array}{c}-0.302^{\star \star \star} \\
(0.11)\end{array}$ & $\begin{array}{c}0.487^{\star \star \star} \\
(0.07)\end{array}$ & $\begin{array}{c}-0.305^{\star \star} \\
(0.13)\end{array}$ \\
\hline eta & $\begin{array}{l}0.273 \\
(0.22)\end{array}$ & $\begin{array}{l}0.580 \\
(0.42)\end{array}$ & $\begin{array}{l}0.294 \\
(0.19)\end{array}$ & $\begin{array}{l}0.663 \\
(0.40)\end{array}$ \\
\hline r_com & $\begin{array}{c}0.575^{\star \star \star *} \\
(0.17)\end{array}$ & $\begin{array}{c}-3.713^{\star \star \star} \\
(0.20)\end{array}$ & $\begin{array}{c}1.155^{\star \star \star} \\
(0.14)\end{array}$ & $\begin{array}{c}-3.709^{\star \star \star} \\
(0.21)\end{array}$ \\
\hline beta & $\begin{array}{c}-0.367^{\star * \star} \\
(0.02)\end{array}$ & $\begin{array}{c}-0.136^{\star \star \star} \\
(0.04)\end{array}$ & $\begin{array}{c}-0.359^{* * *} \\
(0.02)\end{array}$ & $\begin{array}{c}-0.141^{\star * *} \\
(0.04)\end{array}$ \\
\hline idio & $\begin{array}{c}-0.200 * \star \star \\
(0.02)\end{array}$ & $\begin{array}{c}-0.338^{\star \star \star} \\
(0.02)\end{array}$ & $\begin{array}{c}-0.119^{\star \star \star *} \\
(0.02)\end{array}$ & $\begin{array}{c}-0.337^{\star \star \star \star} \\
(0.03)\end{array}$ \\
\hline sbuyback & $\begin{array}{c}-0.615^{\star \star \star} \\
(0.17)\end{array}$ & $\begin{array}{l}0.215 \\
(0.30)\end{array}$ & $\begin{array}{c}-0.621^{\star \star} \\
(0.14)\end{array}$ & $\begin{array}{l}0.208 \\
(0.29)\end{array}$ \\
\hline payer & $\begin{array}{c}1.805^{\star \star \star} \\
(0.18)\end{array}$ & $\begin{array}{c}2.932^{\star \star *} \\
(0.04)\end{array}$ & $\begin{array}{c}0.715^{\star \star \star} \\
(0.07)\end{array}$ & $\begin{array}{c}2.935^{\star \star \star} \\
(0.05)\end{array}$ \\
\hline cash & $\begin{array}{c}0.208^{\star \star \star} \\
(0.10)\end{array}$ & $\begin{array}{c}-0.461^{\star \star \star} \\
(0.14)\end{array}$ & $\begin{array}{c}0.262^{\star \star \star} \\
(0.10)\end{array}$ & $\begin{array}{c}-0.472^{\star \star \star *} \\
(0.14)\end{array}$ \\
\hline reta & $\begin{array}{c}-0.075^{\star \star} \\
(0.04)\end{array}$ & $\begin{array}{c}0.831^{\star \star *} \\
(0.09)\end{array}$ & $\begin{array}{c}-0.161^{\star \star \star} \\
(0.03)\end{array}$ & $\begin{array}{c}0.826^{\star \star \star} \\
(0.10)\end{array}$ \\
\hline ipo90 & & $\begin{array}{l}0.075 \\
(0.05)\end{array}$ & & $\begin{array}{l}0.076 \\
(0.06)\end{array}$ \\
\hline reta*ipo9o & & $\begin{array}{c}-0.754^{\star * *} \\
(0.10)\end{array}$ & & $\begin{array}{c}-0.740^{\star * \star *} \\
(0.13)\end{array}$ \\
\hline taxregime & & $\begin{array}{c}0.421^{\star * *} \\
(0.05)\end{array}$ & & $\begin{array}{c}0.444^{\star \star \star} \\
(0.05)\end{array}$ \\
\hline mills & $\begin{array}{c}0.694^{* \star *} \\
(0.10)\end{array}$ & & & \\
\hline
\end{tabular}


This table reports results for the Heckman sample selection model with 7 CSR sub-dimensions (community relations, corporate governance, diversity, environment, employee relations, the environment, human rights and product safety). In this model, there are two equations called main equation and selection equation, respectively. The dependent variable In the main (selection) equation is dividend payout ratio (propensity to pay dividends) (see Appendix B). Two estimation methods are used and they are two-step estimation (Columns (1) and (2)) and full information maximum likelihood (FIML) estimation (Columns (3) and (4)). For variable definitions see Appendix A. Standard errors are reported in parentheses; * ${ }^{\star *}$ and ${ }^{\star \star *}$ represent significance at the 10 percent, 5 percent and 1 percent level, respectively.

$\wedge$ Robust standard errors are reported for FIML estimates only. 
Figure 1: Frequency Distribution of the Dividend Payout Ratio

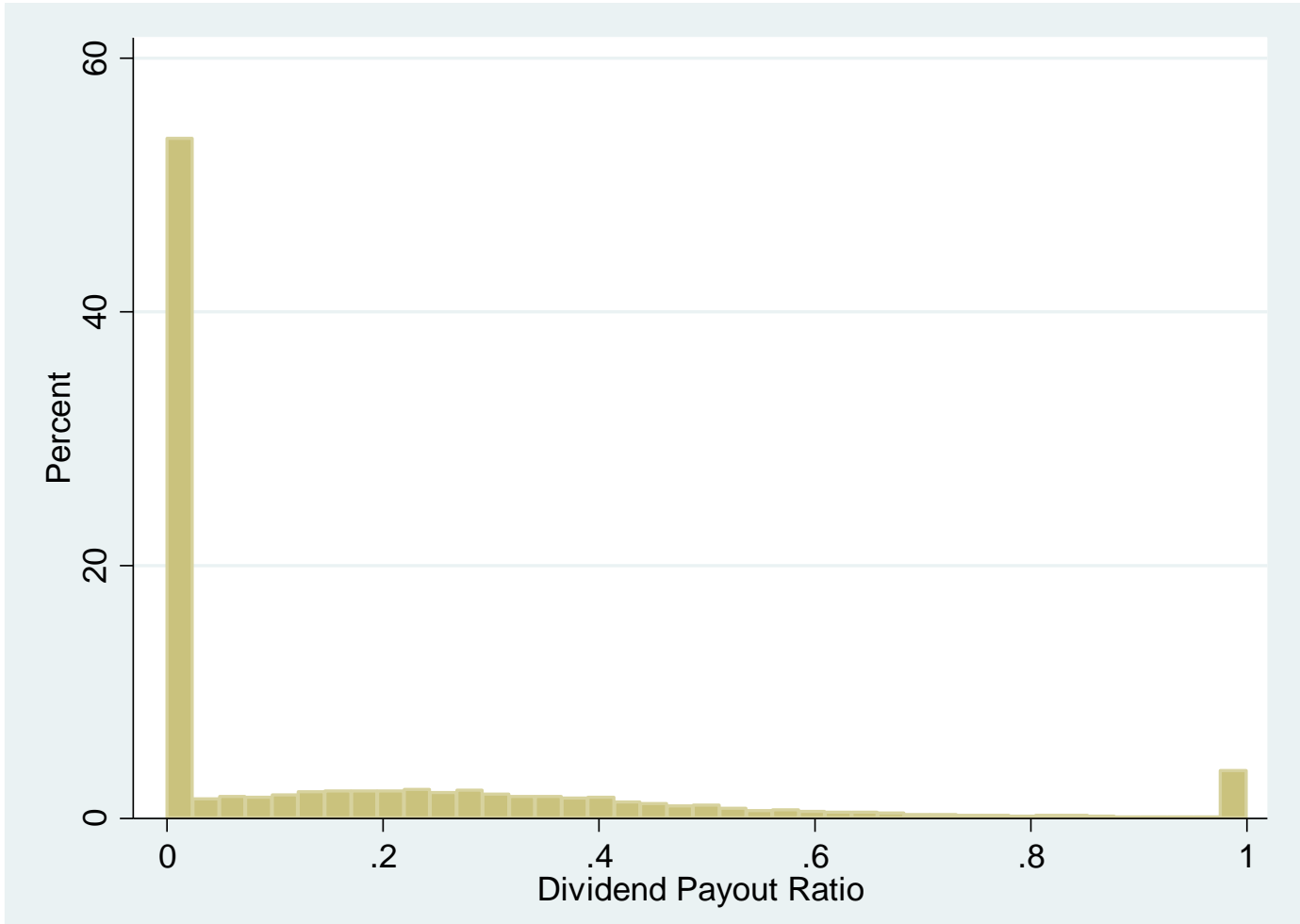

Figure 2: Key variables over time

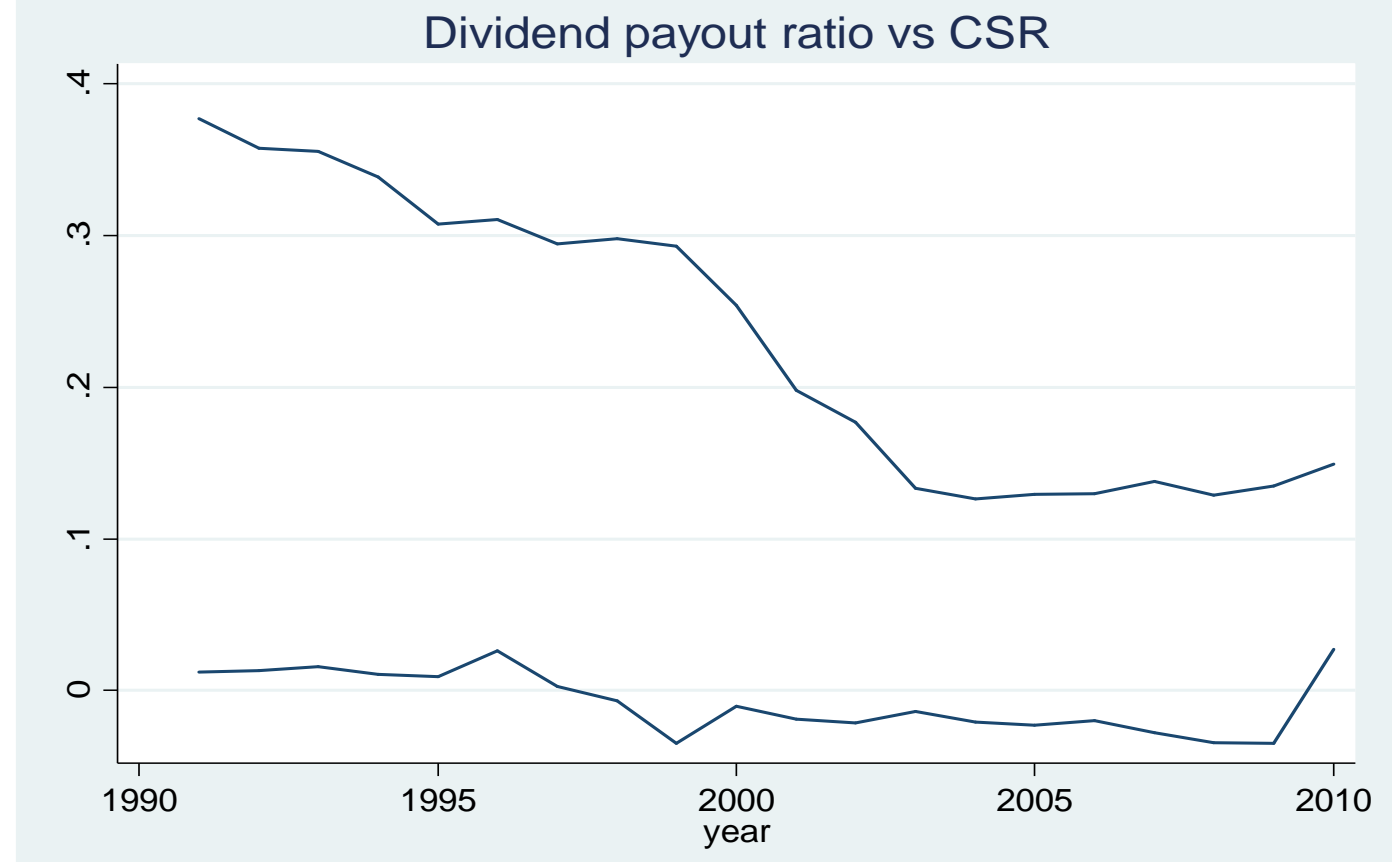

Upper line = Dividend payout ratio;

Bottom line $=$ CSR score 